Research Article

Open Access

Josephine Caust*

\title{
Cultural Rights as Human Rights and the Impact on the Expression of Arts Practices
}

\author{
https://doi.org/10.2478/jcgs-2019-0004
}

"The arts must help give voice to those who aren’t always able to enjoy a platform or have the power to speak up. And it must make some lived experiences more visible.”

Tim Soutphommasane (2017), Australian Human Rights Commissioner

\begin{abstract}
Cultural rights are becoming an increasingly important area of human rights discussion given the association between culture, identity and social equity. The subject is considered here in the context of how the absence of cultural rights influences both the recognition of the diversity of cultures and the capacity of some to access and practice art. Culture and arts practices are intertwined but certain arts practices are prioritised over others by funding bodies, governments and institutions. Recent examples from Australia are highlighted, in which changes to the cultural makeup of the country are occurring at a rapid rate without adequate responses from governments to address funding inequities. It is argued here that unless cultural rights are seen as a basic human right and embedded in the legal national framework, then sectors of the broader community are disenfranchised.
\end{abstract}

Keywords: Cultural rights, arts practices, social equity, identity, freedom of expression

\section{Introduction}

Cultural differences can be a "lightening rod" for protest, push back and inequality. Some cultural issues are related to religion, others are related to racism, identity, freedom of expression and cultural expression. Arts practices are a visible and acknowledged form of cultural expression. While arts practices may seem less contentious than other forms of cultural expression, the reality in many societies is that certain arts practices are supported, through their relationship with governments and various forms of funding, sponsorship and official support, and others not. There is also a hierarchy of arts practice related to class, culture, access, gender, ethnicity and equity. A way to approach these issues is within the framework of "cultural rights".

Cultural rights can be a broad framing, but they do include the notion that all citizens should have access to and be able to participate in the artistic and cultural practices of their choosing (United Nations Human Rights 2013). The terms "culture" and "art" are often intertwined and conflated. There is an extended discussion below about meanings of culture, but in the context of arts practices, culture is seen here as the underpinning or framing for both what and how arts practice is expressed. The term "arts practices" describes practices associated with different art forms, including literature, dance, music, theatre, visual arts and so on. In the case of literature, for example, it may refer to the writing of poetry, fiction or non-fiction, among other practices; in the case of the visual arts it may describe painting,

*Corresponding author: Josephine Caust, The University of Melbourne, Melbourne, Vic Australia, E-mail: jo.caust@unimelb.edu.au 
drawing, sculpture, installations, photography, video art and so on. In contemporary settings, much arts practice is cross disciplinary, so that a writer may work with a dancer and a designer to make a piece that is located across several artforms. Arts practices therefore can be highly specific to one aspect of an art form, or can reflect multiple art forms. The link between art practices and culture can be further extended when a culture favours an art form, say dance, to reflect its values and beliefs. This is well illustrated in the case of Bali, where dance is used to demonstrate traditional stories and myths. Further, different cultures see arts practices from different perspectives. This can be about different perspectives around time and place; for example, the Western perspective sees time in a linear progressive model and makes limited reference to the past, whereas Asian cultures often frame time as circular, where the past and present are interconnected and equally important (Carroll 2015). If the framing of arts practice is done from the perspective of one culture, then perhaps there is limited understanding or respect for the culture and arts practices of another. This lack of understanding or respect may not necessarily be conscious but a product of limited exposure, insularity from other cultures or a belief system that prioritises one's own culture at the expense of others.

There is much acknowledgment by researchers about the inequity of support and access to arts and cultural practices for various communities (Bourdieu 1993; Hesmondhalgh \& Saha 2013; Holden 2010; Koivunen \& Marsio 2007). Likewise, in Australia there has been considerable research on different communities and their access to arts and cultural practices (Ang \& Mar 2016; Australia Council 2017; Blonksi 1992; Diversity Arts Australia et al. 2019; Ho 2017; Ho 2014; Gunew 1994; Mar \& Ang 2015; Psychogios \& Artup 2015; Stevenson et al. 2017). This research describes a complex and changing picture in the Australian context with which governments and their agencies struggle to keep pace. Researchers have pointed out that "...the arts community is much less diverse than the rest of Australia" (Ang \& Mar 2016). It is argued that for historical reasons Anglo-Celtic language and arts practices have been seen as the "norm", and other languages and arts practices are seen as the "other" (Diversity Arts Australia et al. 2019). What is classified then as "professional" arts practice is likely to reflect a narrower cultural framing than the actual cultural make-up of the country (see Blonksi 1992). Over several decades, attempts have been made to broaden understandings of arts and cultural practice by encouraging different government agencies involved with the arts, such as the Australia Council, to change both their funding patterns and definitions (Blonski 1992; Australia Council 2017; Diversity Arts Australia et al. 2019). This has had some success in raising awareness, but it has been an ongoing struggle to shift funding norms. This struggle is related to definitions of "professional" arts practice and its connection with the use of the term "excellence", challenges to shifting funding and the limited or inadequate funding available to meet demand (Ang \& Mar 2016; Blonski 1992; Caust 2017; Eltham \& Verhoeven 2018; Gunew 1994; Khan et al. 2013).

Cultural Rights have been part of the international human rights agenda for more than 70 years, through the work of the United Nations and its agencies. Various conventions relating to cultural rights have been passed by the United Nations Educational, Scientific and Cultural Organisation (UNESCO). However, in the Australian context, the use of cultural rights as a means of addressing funding inequities in the arts sector is not yet common. This paper explores these issues through discussion of the Australian Constitution, work done by the Australian Human Rights Commission and the progress of various states and territories towards introducing cultural rights legislation. Recent data on government priorities and arts funding are also considered here, including publications from the Australia Council (2019, 2018, 2017), Diversity Arts Australia et al. (2019), the Australian Academy of the Humanities (2019) and the Cultural Ministers Statistics Working Group (2018). The combination of this data analysis allows for some conclusions to be drawn about the potential effectiveness of "cultural rights" as a means of ensuring greater social equity in arts funding approaches in the Australian context.

To further this discussion, this paper explores different meanings of culture and the development of cultural conflicts. This will then be considered in the context of recent events in Australia relating to culture and cultural conflict. Current arts practices within a broad community framing and the way government approaches the arts in terms of cultural diversity are then discussed. Finally, we will look at understandings of cultural rights and how they might be applied in the Australian context. 


\section{Culture and cultural conflict}

Raymond Williams (1981) asserted that the term "culture" was one of the most complex terms in the English language and the term continues to be challenging in contemporary settings. How it is understood differs, depending on the context and framing. Avruch (1998) cites varied meanings associated with the term arising from different disciplines. One is an aesthetic definition relating to the high arts, making "culture" an acquired knowledge or skill, another is an anthropological/scientific framing, in which "culture" is seen as the social practices of a group. There is a further expansion of the anthropological approach, where one culture is seen as having no superior value over another. It is noted by some that "culture is complex, ambivalent, and contested" (Hesmondhalgh and Saha 2013: 188). The way we understand the term "culture" can be influenced by our own values, social position, education, gender, race and identity. Thus, the term "culture" does not have an absolute meaning, yet it is often framed as if it does. Citizens talk about their country's "culture" as if it is well understood and fixed. But the reference points being used may be limited to a cultural subset within a larger national framing. Thus, the reflected culture of, say, the middle-class citizen in an urban environment is likely to at times be in opposition to the culture of a working-class citizen in a rural environment.

When we talk about a national culture, we may adopt particular tropes to describe it (Pobjie 2017). For example, the idealised Australian culture is often represented by the great outdoors, the sun bronzed surfer, the notion of the "fair go" and the idea of mateship. But these tropes are limited by gender, location and race. The notion of "mateship" is immediately defined by gender and the notion of "a fair go" only applies to some. Thus, the "idealised" Australian culture is not the culture of everyone, for example, Indigenous Australians or recent immigrants. Yet despite these realities, politicians and the mass media continue to assert that if someone comes to this country, they must adopt the "culture" of the country (based on these false tropes) if they are going to be "real Australians" (Dziedzic \& Belot 2017). How one describes one's culture is therefore influenced by many factors, but the reflected stereotype of what this culture is may apply to a distinct minority of the population. This does not deter conservative and populist commenters from declaring that new immigrants must conform to a narrow and stereotyped notion of culture before they can be truly identified with their adopted country (Bolt 2014).

A recent debate in Australia over a proposal to establish a Centre for Western Civilisation at the Australian National University (ANU) and others, is an interesting case in point (Colebourne 2017). Former Prime Minister Tony Abbott argued that the centre's core purpose was to demonstrate its support of Western civilisation: "The key to understanding the Ramsay Centre for Western Civilisation is that it's not merely about Western civilisation but in favour of it" (Abbott 2018). There is an assumption in Abbot's statement that creating a Centre for Western Civilisation is a way to re-assert the advantages of the Western cultural model over other cultures and thereby re-create a cultural hierarchy rather than enable a critical forum for open discussion. Embedded too in this comment is a desire to frame a discussion of history from a particular perspective and ignore or downplay other narratives (Cairns 2018). Further it can be seen as a backlash reaction to the influence of other cultures on the Australian academic landscape.

Another significant cultural intervention occurred in Australia in May 2017. Up to the present time there is no treaty between the First Nations people of Australia and the European invaders/settlers. In May 2017, around 300 Aboriginal Elders representing the First Nations people of Australia, gathered together from around the country at Uluru, in the centre of the country. There, they developed what they called "The Uluru Statement from the Heart”. As the original and long-serving citizens of Australia, with a history of more than 60,000 years, they asked that they be given their own political forum in Canberra (the national capital) by the more recent residents of the last 200 years.

We seek constitutional reforms to empower our people and take a rightful place in our own country. When we have power over our destiny our children will flourish. They will walk in two worlds and their culture will be a gift to their country. We call for the establishment of a First Nations Voice enshrined in the Constitution. (Uluru Statement from the Heart 2017) 
They note here how the enabling of their voice will also enable the sharing of their culture with the broader population of the country. However, the response by then Prime Minister Malcom Turnbull and other members of his government, was that such recognition would be "undemocratic" in terms of the Australian Constitution (Grattan 2017). The then government also refused to allow the proposal to go to a referendum in which the whole nation would be asked their opinion. These examples illustrate how dynamic and contested issues around culture can be within and between nations. Further, culture is seen as a powerful tool by governments for control, change and influence. It is also seen as a site of contestation between the strong and weak, the colonised and the colonists, the political left and right, and so on.

Over many decades (and centuries) in Australia, cultural identity and cultural rights have been a subject for discussion, research and conflict (Blonski 1992; Gunew 1994; Kendall 2012; Mar \& Ang 2015). The very arrival of European settlers in the eighteenth century started a conflict that is yet to be resolved. By claiming in 1770 that Australia was a "terra nullius", the explorer James Cook asserted that the existing indigenous peoples and their cultures did not exist and therefore did not matter. This concept of Australia was only overturned by the Australian High Court in 1992 as part of the Mabo judgement (see Reconciliation Australia 2017). Further, Australia had a White Australia Policy from the beginning of the twentieth century until a new migration act was passed in 1966 and a policy of multiculturalism was embraced in 1973 by the Whitlam Government (Campbell 2018). More recently, there have been further conflicts around cultural beliefs that impact on legal practices and customs, particularly in the context of a modern democratic state (Kendall 2012). For instance as Kendall (2012) notes, the wearing of a burqua would seem to impinge on the rights of women and exclude the wearer from full social participation, yet the wearer may view the burqua as her right to practise her culture. Moreover, Australia has been slow to sign on to UNESCO conventions around cultural rights and cultural diversity (Mar \& Ang 2015).

\section{Arts practice and culture}

Communities develop arts practices over many years that tell their stories and provide a link to their ancestors. This interconnection between culture and arts practice has been evident from the beginning of human habitation and is documented in early cave paintings and other manifestations of human existence. Art and culture are in a sense always connected because artists are part of the culture they live in and their work reflects the concerns, images and understandings of that culture.

It is also observed that arts practice should reflect a variety of voices (De Beukelaer 2015). It should not be confined to the most powerful or the wealthiest in a society. Virginia Woolf (1929) talked at the beginning of the twentieth century about the need for women to have a room of their own if they were going to write successfully. This example of the need for time and space for creation is part of the argument presented here. Everyone deserves the capacity to find their voice and be able to express it. Likewise, different social, ethnic and cultural groups should have the capacity to express their artistic practices. But for many people, this is not possible because of access and equity issues. Further the use of a language that is not one's first language can also impede cultural and artistic participation, culture, when linked to arts practice, is often a dynamic and flexible concept. Sometimes the term "culture" is used to describe arts practice, so the two terms are conflated.

In the case of Australian Indigenous people for example, arts practice and cultural understandings are intertwined (Cameron 2015). The visual images that are reflected in traditional Australian Indigenous practices are part of the passing down of that community's culture and unique to that community (Brady et al. 2016; Doring \& Nyarrawa 2014). Further, the significance of an artwork is greater than, say, the visual image and has many layers of meaning that span spiritualism, cultural practices, local knowledge, connection with country, and kinship (Brady et al. 2016; Doring \& Nyarrawa 2014). While people may receive pleasure from witnessing this practice, the deeper meanings of the arts practice are not necessarily shared or understood by those outside of the community that produced it (Doring \& Nyarrawa 2014). Visitors have to be educated about the meaning of the art and, in the case of rock art practice, undertake 
the correct protocols of respect before witnessing it (Doring \& Nyarrawa 2014). The arts practice is part of that community's identity and always linked to their culture and knowledge.

In an Australian audience participation survey conducted in 2016, it was recorded that $64 \%$ of the Australian population believed that through exposure to the arts practice of other cultures, they gained a better understanding of the other's culture (Australia Council 2017, 47). This interplay between art and culture is very important, therefore, for both the participant and the observer, giving meaning to the participant and a pathway for understanding to the observer. It is tremendously important then, that a community has access to their arts practices as part of their cultural identity, as well as laying a pathway for respect and understanding from others.

Several researchers have examined particular aspects of arts practice to see how arts practice reflects the Australian population demography. For example, Ho looked at professional theatre production in 2017 and concluded that, "Only 4 out of 95 productions are both written and directed by artists of colour, compared to 70 written and directed by white artists - over seventeen times more.” (Ho 2017, 4). In this example, professional theatre practice demonstrates an imbalanced representation of Australia's demographic and ethnic mix.

In a study published in 2019 by Diversity Arts Australia, the leadership of Australia's arts organisations was reviewed. The study found that in 2018, only $9 \%$ of arts leaders came from a culturally and linguistically diverse (CALD) background (Diversity Arts Australia et al. 2019, 21). In the performing arts this disparity was more extreme, with only $5 \%$ of leaders coming from a CALD background (23). Further, 51\% of major arts organisations had no representation of people from a CALD background in their leadership overall, including their board membership (15).

Researchers in the west of Sydney noted that there was a feeling of frustration and disappointment about the current lack of cultural facilities in the region (Stevenson et al. 2017). The Greater Western Sydney district houses more than $50 \%$ of Sydney's population (which is currently about 4 million), but most of the city's cultural facilities are located in the east or the north of the city. It was recorded, that in 2014, although the Greater Western Sydney population represents 30\% of the state of NSW, the region received only 5.5\% of cultural funding allocated by the NSW Government (Psychogios \& Artup 2015). Further, despite housing 9.5\% of the nation's population, the region received only $1 \%$ of federal arts funding (Psychogios \& Artup 2015). A visual artist noted, "the equity between how much funding the galleries and the institutions in Sydney get as opposed to Western Sydney - there's quite a huge gap. A huge divide...” (Stevenson et al. 2017, 12). Thus, while the wealthier, eastern part of the city has access to a broad array of facilities and generous funding, another part has limited funding and very few facilities. In addition, the west of Sydney is frequently home to new migrants and has a variety of ethnic communities.

Various cultural and arts organisations based in western Sydney and elsewhere have taken a proactive role, embracing and celebrating various cultural and arts practices. Community arts organisations in particular have worked with various CALD communities over many years and have taken a leadership role within the arts funding spectrum to support such activity (Blonski 1992; Gunew 1994). While organisations such as Information and Cultural Exchange (ICE), in the west of Sydney, and Multicultural Arts Victoria have taken a leadership role in this regard, they receive limited funding support and have a relatively low status in the arts hierarchy (Ho 2014; Khan 2013).

\section{What are cultural rights?}

Schafer (2015) argues that "culture" is the missing link required to deal with the present complexity of our world. Thus, recognising a citizen's cultural rights is an acknowledgement of the importance of culture for our future. Cultural rights were embedded in the initial Declaration on Human Rights in 1948, in Article 27 of the declaration, which states that citizens "should have the right to participate in cultural life". Cultural rights therefore are an important facet of human rights that need recognition. Symonides (1998) wrote that although cultural rights had always been included in the initial Declaration of Human Rights, they were 
generally forgotten about, aside from the "right to an education". However, three important conventions have been passed by UNESCO to protect cultural practices and heritage. These are the:

- Convention Concerning the Protection of the World Cultural and Natural Heritage (UNESCO 1972)

- Convention for the Safeguarding of the Intangible Cultural Heritage (UNESCO 2003)

- Convention on the Protection and Promotion of the Diversity of Cultural Expression (UNESCO 2005)

Principle 1 of the 2005 UNESCO Convention states,

Cultural diversity can be protected and promoted only if human rights and fundamental freedoms, such as freedom of expression, information and communication, as well as the ability of individuals to choose cultural expressions, are guaranteed. No one may invoke the provisions of this Convention in order to infringe human rights and fundamental freedoms as enshrined in the Universal Declaration of Human Rights or guaranteed by international law, or to limit the scope thereof. (UNESCO Article 2, 2005)

Thus there is acknowledgement here that cultural rights are a fundamental expression of human rights. But the notion of cultural rights as something that can be included in a nation's bill of rights or similar, has only recently received broader recognition. Australia only became a signatory to the 2005 Convention in 2009, but as a signatory has an obligation to adhere to expectations of the Convention by encouraging, protecting and promoting diversity of cultural expression (Mar \& Ang 2015).

It is long recognised that inequities exist in relation to both cultural expression and arts practice because of class, education, race and gender (Bourdieu 1993; Conor et al. 2015; Gray 2012; Holden 2010). Culture is a fundamental part of this discussion. As noted previously, there has only been recent recognition (despite the 1948 Human Rights Declaration) that citizens of a country should have "cultural" rights as much as they should have political or social rights (UNESCO 2005). While the acknowledgement of cultural rights is relatively recent, the way the concept is understood and practiced can differ (Hsin-Tien 2015; Portolés \& Šešić 2017; Wang 2014). Cultural rights then in this context are seen as basic human rights.

Cultural rights comprise an aspect of human rights in that they are universal in character and guarantee all persons the right to access their culture. (Barth 2008, 79)

This is also an acknowledgement that a community may have distinctive cultural practices based on cultural beliefs and traditions that define their community. Thus, ignoring or disregarding these practices potentially destroys the framework of that community. Further, there is recognition that the protection of cultural rights is an important public interest issue that is in the long-term interest of humanity (Francioni 2008). This is described also as an affirmation of one's own identity and the need for autonomy (Barth 2008).

In 2001, UNESCO passed its Universal Declaration on Cultural Diversity (UNESCO 2001). This declared that all peoples had the right to experience and practice their own cultures or in other words had cultural rights. In the 2003 UNESCO Convention, it was observed that intangible cultural heritage was "a mainspring of cultural diversity" defining it as,

... the practices, representations, expressions, knowledge, skills - as well as the instruments, objects, artefacts and cultural spaces associated therewith - that communities, groups and, in some cases, individuals recognize as part of their cultural heritage. (UNESCO 2003, Article 2)

"Intangible cultural heritage" often describes arts practices, such as traditional dances, storytelling, music or performances, that are part of a community's cultural practices rather than tangible cultural heritage characterised by, say, physical structures. The 2005 UNESCO Convention recorded that cultural diversity is in the long-term interests of humanity and notes that achieving cultural diversity and the affirmation of cultural rights depends on freedom of expression being allowed and encouraged. This recognition that cultural diversity and by direct association, cultural rights, are dependent on the recognition and guarantee of human rights, is critical to seeing what is required legally to ensure that these principles are 
applied. Further within the UNESCO convention is the recognition that the enabling of cultural diversity requires equal access to its expression. Principle 7 notes therefore,

Equitable access to a rich and diversified range of cultural expressions from all over the world and access of cultures to the means of expressions and dissemination constitute important elements for enhancing cultural diversity and encouraging mutual understanding. (UNESCO 2005, Article 2)

Thus, unless a nation state, or nations combined, provide and allow equity of access, then the capacity to experience cultural diversity or express one's cultural rights is not possible. So, this suggests that legal intervention is necessary for cultural rights to be enacted. It is becoming recognised too that cultural rights are a basic human right that are critical for a society to function in a free, just and democratic mode (Portolés \& Šešić 2017). This means that nations need to address constitutional issues that embrace human rights to allow for cultural rights. As Wang $(2014,26)$ notes, “...governments have a role to play in ensuring the production and circulation of a diversity of cultural products reflecting the different values and meanings comprising the makeup of civil society”. Some nations have begun a process of cultural rights recognition. In Taiwan, for example, there has been an embrace by government of citizens' cultural rights (Hsin-Tien 2015; Wang 2014). When Taiwan had a national election in 2012, all the major parties and their candidates addressed the need for cultural rights, for example in a live television debate the three leadership candidates described how they would approach cultural rights and cultural policy (Hsin-Tien 2015). This focus on cultural rights is seen as an essential facet of their citizens' rights. Other nations have embedded cultural rights in their approach to cultural policy for many years. For example, Sweden embedded conventions around cultural rights in the formulation of their first cultural policy in 1974 (Koivunen \& Marsio 2007). Finland went further and embedded cultural rights into their constitution in 2000 (Koivunen \& Marsio 2007).

International groups have embraced the recognition of cultural rights. For example the United Cities and Local Governments (UCLG), a global network of cities, local and regional governments, adopted the Agenda 21 for Culture. It has 67 articles, divided into three sections: principles, undertakings, and recommendations (Agenda 21 2008). The principles include core values such as cultural diversity and human rights, and culture itself is described as an essential part of constructing citizenship for people of all ages. The intent of this document and program is to embed principles of cultural development at the local level. It is noted in Agenda $21(2008,5)$ that cultural rights are an integral part of human rights. "No one may invoke cultural diversity to infringe upon the human rights guaranteed by international law, nor to limit their scope". This statement draws attention to the connection between human rights in general and cultural rights in particular. The UCLG website notes that by 2015 more than 500 local governments and regions internationally had committed themselves to undertaking Agenda 21 for Culture (2008).

In 2009, the United Nations Human Rights Office of the High Commissioner appointed an independent cultural rights expert, since 2012 known as the the Special Rapporteur in the Field of Cultural Rights. This person's role is to report to both the Human Rights Council and the United Nations General Assembly on a yearly basis. The role has several responsibilities but two that have relevance to this discussion are:

(b) Identify possible obstacles to the promotion and protection of cultural rights, and submit proposals and/or recommendations to the Council on possible actions in that regard;

(d) Study the relationship between cultural rights and cultural diversity, in close collaboration with States and other relevant actors, including in particular the United Nations Educational, Scientific and Cultural Organization, with the aim of further promoting cultural rights (see United Nations Human Rights Office of the High Commission 2009).

In 2013, the special rapporteur delivered a report to the United Nations General Assembly on "The right to freedom of artistic expression and creativity". In her report she noted, "The Special Rapporteur encourages States to critically review their legislation and practices imposing restrictions on the right to freedom of artistic expression and creativity, taking into consideration their obligations to respect, protect and fulfil 
this right” (Shaheed 2013, 1). She further noted that there were legal restrictions in many states that did not allow for "freedom of expression". In particular she observed that,

State cultural policies need to take artistic freedoms into consideration, in particular when establishing criteria for selecting artists or institutions for State support, the bodies in charge of allocating grants, as well as their terms of reference and rules of procedure. The system in place can help to avoid undue government influence on the arts. (Shaheed 2013,16)

This particular recommendation has direct relevance to Australia.

\section{The Australian Context}

There are challenges to including "cultural rights" in the Australia's constitution. The Australian Constitution focuses primarily on the arrangements between the federal body and the states bodies, defining jurisdictions and decision-making responsibilities, and the powers of parliament. There is no mention of human rights within the document. Australia is the only Western democracy that does not have a bill or charter of rights for its citizens. Further, as noted earlier, it has no treaty with its original inhabitants. However, several parliamentary acts cover aspects of human rights, such as the Racial Discrimination Act of 1975. Through these acts of parliament, fairer and more equitable policies and legislation have been introduced over time in Australia, which clarify the rights and responsibilities of citizens. Moreover, the High Court of Australia has held that there is an "implied freedom of political communication", reflecting the representative government that exists at both state and federal level, although the meaning of this is contested (see Australian Human Rights Commission 2013a). The 1948 International Declaration of Human Rights was supported by the Australian government at the time of its passing. Many of the covenants that came out of the original declaration, including the International Covenant on Economic, Social and Cultural Rights (1966), reflected Article 27 of the original declaration. Article 15 of the 1966 Covenant also notes that "The States Parties to the present Covenant recognize the right of everyone: (a) To take part in cultural life...” (United Nations Human Rights 1966).

The Australian Human Rights Commission (AHRC) is a government statutory authority that reports to parliament through the attorney general (see Australian Human Rights Commission 2012). It exists to support and review human rights in all aspects of Australian law and practice and "...has a responsibility to monitor Australia's performance in meeting its international human rights commitments..." (Australian Human Rights Commission 2010). The AHRC website notes that many Australian citizens' rights are not protected by the Australian Constitution, including freedom of expression and cultural rights, which are not protected or enshrined in Australian laws (Australian Human Rights Commission 2013b). The AHRC argues that Australia should adopt a national human rights law (commonly called a charter of rights) as a means of addressing the anomalies and gaps that presently exist in the Australian Constitution and acts of parliament. In 2009, the then Australian Human Rights Commissioner, Graham Innes said, "A Human Rights Act would make public servants take human rights into account when making decisions and delivering services” (Innes 2009). Recent police actions against the media and whistle-blowers in Australia has led to the nation being described internationally as the world's most secretive Western democracy (Cave 2019). These are all issues raised by the Special Rapporteur in the Field of Cultural Rights.

Although there has been no action to establish a human rights act at the federal level in Australia, two states and one territory have introduced a charter or bill of rights. The first act to address human rights was passed in the Australian Capital Territory (ACT) in 2004 (Australasian Legal Information Institute 2004). Section 27 of the Human Rights Act 2004 addresses the cultural and other rights of Aboriginal and Torres Strait Islander peoples and other minorities:

(1) Anyone who belongs to an ethnic, religious or linguistic minority must not be denied the right, with other members of the minority, to enjoy his or her culture, to declare and practise his or her religion, or to use his or her language. 
(2) Aboriginal and Torres Strait Islander peoples hold distinct cultural rights and must not be denied the right-

(a) to maintain, control, protect and develop their-

(i) cultural heritage and distinctive spiritual practices, observances, beliefs and teachings; and

(ii) languages and knowledge; and

(iii) kinship ties; and

(b) to have their material and economic relationships with the land and waters and other resources with which they have a connection under traditional laws and customs recognised and valued (see Australasian Legal Information Institute 2004).

In 2006 the state of Victoria introduced a Charter of Human Rights and Responsibilities Act. Section 19 of the charter notes that,

All persons with a particular cultural, religious, racial or linguistic background must not be denied the right, in community with other persons of that background, to enjoy his or her culture (see Australasian Legal Information Institute 2006).

The Victorian charter also makes special mention of the cultural rights of Aboriginal and Torres Strait Islander people and the need to honour their rights. In February 2019, Queensland was the third state/territory to pass a Human Rights Act. Under Section 27 of the Queensland Act there is a provision for cultural rights in general and Section 28 addresses the cultural rights of Aboriginal and Torres Strait Islander people in particular, noting that, "Aboriginal peoples and Torres Strait Islander peoples have the right not to be subjected to forced assimilation or destruction of their culture (Queensland Government 2019).

A significant issue for planners and policymakers is the rapid change in the cultural make-up of Australia's population. According to the Australian Bureau of Statistics (ABS) the increase in Australia's population since the early 2000s is largely due to migration, which accounts for around $64 \%$ of the population growth (Simon-Davies 2018). In the 1954 Australian census, non-European countries did not get a mention in the top ten migrant countries of origin (Simon-Davies 2018). By the 2001 census, the top ten countries of origin of new migrants included 12.2\% coming from non-European countries (Simon-Davies 2018). Then, according to the 2016 census, of the top ten country of origin of new migrants coming to Australia, over $29 \%$ of migrants came from non-European countries (Simon-Davies 2018). A further study of ABS data concluded that in 2018,39\% of the Australian population came from a background not purely Anglo-Celtic and 3\% of the population has First Nations heritage (Simon-Davies 2018). This is a considerable change in the cultural makeup of the Australian population over a relatively short period of time.

In its 2018 federal budget, the federal government predicted an overall expenditure of A $\$ 488.58$ billion (Kesper et al. 2018). Within this total, A $\$ 1.3$ billion - a little more than a quarter of $1 \%$ - was allocated to arts and cultural heritage (Kesper et al. 2018). According to World Bank data, in 2018 Australia was the $20^{\text {th }}$ most wealthy nation in the world, ahead of Canada, Japan and France (Harrington 2018). While there are caveats when doing direct comparisons, Australia spent around $\$ 95$ per capita federally, including recurrent expenditure (but not including local and state contributions), on arts and cultural heritage in 2016-17 (Cultural Ministers Statistics Working Group 2018). In 2015, Sweden, which is listed as $18^{\text {th }}$ on the world bank list, only two places ahead of Australia, had a public cultural expenditure of $\$ 439$ per capita and Estonia, which is well below Australia and Sweden on the wealth list, spent around \$337 per capita (Council of Europe 2017). Further, a recent report on cultural and arts expenditure in Australia noted that in the context of the Organisation for Economic Co-Operation and Development (OECD) countries, Australia ranked 26 out of 33 countries in their overall expenditure on culture, recreation and religion, with a total of 0.72 per cent of per capita expenditure, considerably below the OECD average of 1.11 per cent per capita (Australian Academy of the Humanities 2019, 5). It is also noted that in Australia "per capita public expenditure on culture has dropped by 4.9 per cent over the decade 2007-08 to 2017-18" (Australian Academy of the Humanities 2019, 5). It is argued in the report that this drop reflects the government's inability to keep up with population growth (Australian Academy of the Humanities 2019, 5). 
In 2017-2018, the Australia Council, the national arts funding body, had a budget of $\mathrm{A} \$ 189.3$ million to spend on the funding of arts activities. Around 59\% of this total (or $\$ 111$ million) went to support the 28 major performing arts organisations that are included in the Major Performing Arts Framework. These organisations are primarily dominated by opera, symphony orchestras and ballet companies, which are framed on a European cultural heritage model (Australia Council 2018). Over 2018 and into 2019, the Australia Council has been reviewing this framework and consulting with the broader arts sector for its review. In a summary of the second phase of consultation, the council noted there was "little diversity" among this group of major performing arts organisations and only one Indigenous company (Bangarra Dance Theatre) was included. In the latest Australia Council Strategic Plan (2019), Creativity Connects Us, an objective that addresses the need for cultural diversity states, "We will support equity of opportunity and access in our creative expression, workforce, leaders and audiences" (Australia Council 2019). A key performance criterion for measuring this is articulated as "Supporting at least 200 culturally diverse applications with total funding of \$13 million provided per year” (Australia Council 2019).

If A $\$ 13$ million of the Australia Council's present funding was allocated to culturally diverse activity as promised, that would only represent around $7 \%$ of the Council's total arts funding. This percentage is not reflective of the cultural diversity of the country as it now stands. In 2016 the non-European ethnicity of the population was recorded as $15 \%$ of the population by the ABS and in 2018, the ABS recorded that $29 \%$ of the population were born overseas (Simon-Davies 2018).

Inequities exist in Australia in the distribution of arts funding and the provision of cultural facilities within cities, states and across the country. In addition, some communities are favoured and others are not. It is incumbent on governments to ensure that its citizens receive equal treatment. It is argued here that recognising "cultural rights" as a means of doing this may bring about more legal pressure on governments and other bodies to ensure greater equity. The states appear to be leading the way in introducing bills of rights and enacting legislation that will support fairer policies in the future. However, Australia needs to address the issue as a matter of national importance. If in Australia's case, there was a bill of rights that included cultural rights, there could be the capacity to enforce greater equity in the distribution of arts funding, as well as ensure the fairer provision of cultural facilities currently provided by governments at all levels.

However, there are significant obstacles in Australia for this to occur in the short term. These include a reluctance by successive conservative governments to address most aspects of cultural rights or enact any legislation that might change funding ratios or create a more level playing field. In July 2019, the present Minister for Indigenous Affairs, Ken Wyatt, promised to have a referendum to address the constitutional recognition of Australia's First Nations people within the next three years (Remeikis 2019). Whether this occurs remains to be seen, but it is the first time a commitment has been made. Given Australia's economic position, it is in a position to demonstrate more financial generosity towards ensuring all Australian have access to cultural facilities and to experience the arts practices that are part of their culture (Australian Academy of the Humanities 2019). However, this requires a significant change in the current government's approach.

Democratic governments have a human rights obligation to ensure that their citizens are treated fairly and equitably. As argued here, cultural rights are part of the spectrum of human rights. Without the capacity to legally enforce the cultural rights of citizens, it is likely that many members of a community will have limited access to arts and cultural facilities. In addition, their capacity to make art or undertake creative activities that are central to their identity, may be restricted. The importance of allowing and encouraging distinct arts and cultural practices has been acknowledged in different ways by the Universal Declaration on Cultural Diversity (2005). However, when reviewing patterns of arts funding, provision of cultural facilities and positive approaches to the representation of diverse voices, there is little evidence that in Australia's case governments are acting to ensure this. There is still considerable "push back" by conservative voices who wish to celebrate a purely Euro-centric approach to both art and culture (Eltham and Verhoeven 2015). As another researcher has pointed out, “...we need to re-map arts policy to reflect our geography and cultural diversity” (Pledger 2015). 


\section{Conclusion}

Modern societies are complex, multi-layered and diverse. There is not the homogeneity of culture that may have been evident in some nation states 100 years ago. Migration is now a reality for all countries, and this has ensured that many different cultural communities exist alongside each other. To assert, therefore that there is a homogenous national culture is both naïve and elitist. As new migrants bring different cultures and arts practices with them, there is a necessity to recognise that a cultural diversity exists. In Australia's case, this cultural diversity is underpinned by the presence of the oldest, living continuous culture on this earth, that of the Australian Aboriginal or First Nations People. These deep cultural resources need to be acknowledged, celebrated and reflected in our national approach to culture and the arts.

In Australia at present, many communities suffer disadvantage because of their inability to express and practice their culture and experience the arts practices that are central to it. Arts funding and the provision of cultural facilities are inadequate and are unfairly distributed in terms of geography and cultural framings. Cultural rights as a constitutional means to address this inequity may be an important way forward. If Australia wants to truly embrace its culturally diverse communities, then many significant changes need to occur. While a recognition of cultural rights may not solve all of these issues, it will provide a stronger legislative framework to influence government policies and current arts funding approaches.

\section{Acknowledgement}

The author would like to thank the anonymous reviewers for their generous advice and suggestions.

\section{References}

Abbott, T. 2018 “Paul Ramsay’s vision for Australia” Quadrant Online, May 24. Available at: https://quadrant.org.au/ magazine/2018/04/paul-ramsays-vision-australia/

Agenda 21 for Culture. 2008. Committee on culture - United Cities and Local Governments - UCLG. Available at: www. agenda21culture.net/sites/default/files/files/documents/multi/ag21_en.pdf

Ang I. \& Mar P. (2016) “Australia's arts community has a big diversity problem - that's our loss." The Conversation, 21 January. Available at: https://theconversation.com/australias-arts-community-has-a-big-diversity-problem-thats-ourloss-52686

Australasian Legal Information Institute. 2004. Australian Capital Territory Current Acts, Human Rights Act 2004. Available at: http://www7.austlii.edu.au/cgi-bin/viewdoc/au/legis/act/consol_act/hra2004148/s27.html

Australasian Legal Information Institute. 2006. Charter of Human Rights and Responsibilities Act 2006. accessed at: http:// www8.austlii.edu.au/cgi-bin/viewdoc/au/legis/vic/consol_act/cohrara2006433/index.html

Australia Council. 2017. Connecting Australians: results of the national arts participation survey. Available at: http://www. australiacouncil.gov.au/research/connecting-australians/

Australia Council. 2018. Australia Council Annual Report 2017-18. Available at: https://www.australiacouncil.gov.au/ workspace/uploads/files/australia-council-annual-repor-5bd8e5e63c2c6.pdf

Australia Council. 2019. Corporate Plan 2019-2013. Creativity Connects Us. Available at: https://www.australiacouncil.gov. au/workspace/uploads/files/australia-council-corporate-pl-5d68738684ece.pdf

Australian Academy of the Humanities. 2019. The big picture: Public expenditure on artistic, cultural and creative activity in Australia, Executive Summary. Acton, ACT: A New Approach.

Australian Human Rights Commission. 2010. Let’s talk about rights - Human Rights Act for Australia. Available at: https:// www.humanrights.gov.au/our-work/rights-and-freedoms/projects/lets-talk-about-rights-human-rights-act-australia

Australian Human Rights Commission. 2012. About rights and freedoms. Available at: https://www.humanrights.gov.au/ourwork/rights-and-freedoms/about-rights-and-freedoms

Australian Human Rights Commission. 2013a. Freedom of information, opinion and expression. Available at : https://www. humanrights.gov.au/our-work/rights-and-freedoms/freedom-information-opinion-and-expression

Australian Human Rights Commission. 2013b. "Rights to enjoy and benefit from culture" ICESER Article 15. Available at: https://www.humanrights.gov.au/rights-enjoy-and-benefit-culture[JL2]

Avruch, K. 1998. Culture and Conflict Resolution. Washington, DC: United States Institute of Peace Press. 
Barth, K. W. 2008. "Cultural rights: A necessary corrective to the nation state” In F. Francioni \& M. Scheinin (Eds.). 2008. Cultural Human Rights International Studies in Human Rights, pp. 79回90. Leiden, Netherlands: Martinus Nijhoff Publishers.

Blonski, A. 1992. Arts for a multicultural Australia 1973-1991 - An account of Australia Council policies. Sydney: Australia Council for the Arts.

Bolt, A. 2014. Australia being asked to assimilate to immigrant values. SBS News. 6 August 2014. Available: https://www. sbs.com.au/news/australia-being-asked-to-assimilate-to-immigrant-values-bolt-says

Bourdieu, P. 1993. The field of cultural production: essays on art and literature. Cambridge, England: Polity Press.

Brady, L. M., J. J. Bradley, and A. J. Kearney. 2016. "Negotiating Yanyuwa rock art relational and affectual experiences in the Southwest Gulf of Carpentaria, Northern Australia." Current Anthropology 57 (1): 28-52.

Cairns, R. 2018. "Western civilisation? History teaching has moved on, and so should those who champion it." The Conversation, June $6^{\text {th }}$. Available at: https://theconversation.com/western-civilisation-history-teaching-has-moved-onand-so-should-those-who-champion-it-97697

Cameron, E. 2015. “Is it art or knowledge? Deconstructing Australian Aboriginal creative making.” Arts 4 (2): 68-74.

Campbell, D. 2018. "Fact check: Did former prime minister Harold Holt abolish the White Australia policy?” ABC News 14 Dec. Available at: https://www.abc.net.au/news/2018-09-06/fact-check-did-harold-holt-abolish-the-white-australiapolicy/10194408

Carroll, A. 2015. "Vive la differénce! Taking advantage of cultural difference in international arts exchanges with Asia and more broadly." In J Caust, Arts and Cultural Leadership in Asia, Routledge Advance in Asia Pacific Studies Series. Abingdon, UK: Routledge.

Caust, J. 2017. "The continuing saga around arts funding and the cultural wars in Australia." International Journal of Cultural Policy 1-15.

Cave, D. 2019. "Australia may well be the World's most secretive democracy." New York Times, 5 June. Available at: https:// www.nytimes.com/2019/06/05/world/australia/journalist-raids.html

Colebourne, C. 2017. "The concept of 'western civilisation' is past its use-by date in university humanities departments." The Conversation, 20 November. Available at: https://theconversation.com/the-concept-of-western-civilisation-is-past-itsuse-by-date-in-university-humanities-departments-87750

Conor, B., R. Gill, and S. Taylor. 2015. “Gender and Creative Labour.” Sociological Review 63 (1): 1-22.

Council of Europe. 2017. "Monitoring Public Cultural Expenditure in Selected European Countries 2000-2015." Compendium: Cultural Policies and Trends in Europe. Available at: https://www.culturalpolicies.net/web/statistics-funding. php?aid $=232$ \& cid $=80$

Cultural Ministers Statistics Working Group. 2018. Cultural funding by government 2016-17. Available at: www.arts.gov.au/ documents/cultural-funding-government-2016-17

De Beukelaer, C. 2015. Developing Cultural Industries; Learning from the Palimpsest of Practice. European Cultural Foundation:0 Amsterdam.

Diversity Arts Australia, BYP Group, \& Western Sydney University. 2019. Shifting the Balance: Cultural Diversity in Leadership within the Australian Arts, Screen and Creative Sectors. Sydney: Diversity Arts Australia.

Doring, J., and P. Nyawarra. 2014. "Gwion Artists and Wunan Law: The Origin of Society in Australia." Rock Art Research 31 (1): 1-12.

Dziedzic, S. and Belot, H. 2017. "Australian citizenship law changes mean migrants will face tougher tests." ABC News 20 April. Available at: https://www.abc.net.au/news/2017-04-20/migrants-to-face-tougher-tests-for-australiancitizenship/8456392

Eltham, B. and Verhoeven, D. 2015. "Philosophy vs evidence is no way to orchestrate cultural policy." The Conversation 29 May. Available at: http://theconversation.com/philosophy-vs-evidence-is-no-way-to-orchestrate-cultural-policy-42487

Eltham, B. C., and D. Verhoeven. 2018. "A 'natural experiment' in Australian cultural policy: Australian Government funding cuts disproportionately affect companies that produce more new work and have larger audiences." International Journal of Cultural Policy 1-14.

Francioni, F. 2008. "Culture Heritage and Human Rights: An Introduction.” In Cultural Human Rights International Studies in Human Rights, ed. F. Francioni and M. Scheinin. Leiden: Martinus Nijhoff Publishers. https://doi.org/10.1163/ ej.9789004162945.i-372.5.

Gunew, S. 1994. 'Arts for a multicultural Australia: Redefining the culture'. In Culture, Difference and the Arts, edited by S. Gunew \& F. Rizvi. St Leonards, NSW: Allen \& Unwin.

Grattan, M. 2017. “Turnbull government says no to Indigenous 'Voice to Parliament”' 26 October, The Conversation. Available at: https://theconversation.com/turnbull-government-says-no-to-indigenous-voice-to-parliament-86421

Gray, C. 2012. “Democratic Cultural Policy: Democratic forms and Policy Consequences.” International Journal of Cultural Policy 18 (5): 505-18.

Innes, G. 2009. A Human Rights Act for Australia. Available at: https://www.humanrights.gov.au/about/news/speeches/ human-rights-act-australia

Harrington, J. 2018. "From Bahrain to Qatar: These are the 25 richest countries in the world." 28 November USA Today. Available at: https://www.usatoday.com/story/money/2018/11/28/richest-countries-world-2018-top-25/38429481/ 
Hesmondhalgh, D., and A. Saha. 2013. "Race, ethnicity, and cultural production.” Popular Communication 11 (3): 179-95. Ho, C. 2014. "Creativity, Culture and Cosmopolitanism: Community Arts in Multicultural Sydney." Japan Social Innovation Journal 4 (1): 1-8.

Ho, K. 2017. Cultural Diversity in Australian Theatre: a statistical analysis of theatre programming. Available at: https://drive. google.com/file/d/OByYXTEOWqfjtMEpnR3l1aTFGeGM/view

Holden, J. 2010. Culture and Class. London: Counterpoint/British Council. Availble at; www.bluedrum.ie/documents/ CultureAndClassStandard.pdf.

Hsin-Tien, L. 2015. “Interlocution and engagement: cultural policy sphere and culture policy in Taiwan." In Arts and Cultural Leadership in Asia, ed. J. Caust, 48-58. Routledge Advance in Asia Pacific Studies Series. Abingdon, UK: Routledge.

Kendall, H. 2012. “Clothing and Punishment: Cultural Rights in Australia." In Right Now, Human Rights in Australia May 8. Available at: http://rightnow.org.au/opinion-3/clothing-and-punishment-cultural-rights-in-australia/

Kesper, A., Elvery, S. \& Spraggon, B. 2018. “Budget 2018: Where every dollar comes from, and how it's spent." $A B C$ News 8 May. Available at: https://www.abc.net.au/news/2018-05-08/federal-budget-2018-sliced-dicedinteractive/9723604\#spending/breakdown/2019/social-security-and-welfare

Khan, R., D. Wyatt, A. Yue, and N. Papastergiadis. 2013. "Creative Australia and the Dispersal of Multiculturalism." Asia Pacific Journal of Arts and Cultural Management 10 (1): 25-34.

Koivunen, H. \& Marsio, L. 2007. Fair Culture? Ethical dimension of cultural policy and cultural rights. Ministry of Education Finland. Available at: https://www.culturalpolicies.net/web/files/47/en/FairCulture.pdf

Mar, P., and I. Ang. 2015. Promoting Diversity of Cultural Expression in Arts in Australia: Case Study Report. Sydney: Australia Council for the Arts.

Pledger, D. 2015. “Finding our identity: arts policy and the future." The Conversation September 28. Available at: https:// theconversation.com/finding-our-identity-arts-policy-and-the-future-48091

Pobjie, B. 2017. "The 10 most Australian values that make Australia so valuable" ABC News 28 April. Available at: https:// www.abc.net.au/news/2017-04-28/these-are-our-core-australian-values/8476902

Portolés, J. B., and M. D. Šešić. 2017. "Cultural rights and their contribution to sustainable development: Implications for cultural policy.” International Journal of Cultural Policy 23 (2): 159-73.

Psychogios, T., and B. Artup. 2015. Building Western Sydney's Cultural Arts Economy - a key to Sydney's success. Sydney: Deloitte.

Queensland Government. 2019. Human Rights Act 2019. Available at: https://www.legislation.qld.gov.au/view/html/ asmade/act-2019-005\#sec. 27

Reconciliation Australia. 2017. National Reconciliation Week 2017. Available at: https://www.reconciliation.org.au/ wp-content/uploads/2017/11/mabo-decision_2017.pdf

Remeikis, A. 2019. "Ken Wyatt wants referendum on Indigenous constitutional recognition within three years." July 10 The Guardian. Available at: https://www.theguardian.com/australia-news/2019/jul/10/ken-wyatt-wants-referendum-onindigenous-constitutional-recognition-within-three-years

Schafer, D. P. 2015. The Secrets of Culture. Oakville, Canada: Rock's Mill Press.

Shaheed, F. 2013. "The right to freedom of artistic expression and creativity" Report of the Special Rapporteur in the field of cultural rights. United Nations General Assembly 14 March. Available at: https://documents-dds-ny.un.org/doc/ UNDOC/GEN/G13/118/44/PDF/G1311844.pdf?OpenElement

Simon-Davies, J. 2018. "Population and migration statistics in Australia 7 December 2018” Canberra: Parliament of Australia, Parliamentary Library. Available at: https://www.aph.gov.au/About_Parliament/Parliamentary_Departments/ Parliamentary_Library/pubs/rp/rp1819/Quick_Guides/PopulationStatistics

Soutphommasane, T. 2017. "Cultural Diversity and the Arts.” Available at: https://www.humanrights.gov.au/about/news/ speeches/cultural-diversity-and-arts

Stevenson, D., D. Rowe, J. Caust, and C. Cmielewski. 2017. Recalibrating Culture: Production, Consumption, Policy. Sydney: Institute for Culture and Society, Western Sydney University; Available at https://www.westernsydney.edu.au/_data/ assets/pdf_file/0006/1239999/recalibrating-culture-report.pdf.

Symonides, J. 1998. “Cultural Rights a Neglected Category of Human Rights.” International Social Science Journal 50 (158): 559-72.

Uluru Statement from the Heart. 2017. Available at: https://www.referendumcouncil.org.au/sites/default/files/2017-05/ Uluru_Statement_From_The_Heart_0.PDF

UNESCO. 1972. Convention Concerning the Protection of the World Cultural and Natural Heritage. Available at: https://whc. unesco.org/en/conventiontext/

UNESCO. 2001. UNESCO Universal Declaration on Cultural Diversity. Available at: http://portal.unesco.org/en/ev.php-URL_ ID=13179\&URL_DO=DO_TOPIC\&URL_SECTION=201.html

UNESCO. 2003. UNESCO Convention for the Safeguarding of the Intangible Cultural Heritage. Paris: UNESCO. http://portal. unesco.org/en/ev.php-URL_ID=17716\&URL_DO=DO_TOPIC\&URL_SECTION=201.html

UNESCO. 2005. UNESCO Convention on the Protection and Promotion of the Diversity of Cultural Expressions. Paris: UNESCO. Available at: https://en.unesco.org/creativity/convention 
United Nations Human Rights, Office of the High Commissioner. 1966. "International Covenant on Economic, Social and Cultural Rights.” Available at: https://www.ohchr.org/EN/Professionallnterest/Pages/CESCR.aspx

United Nations Human Rights, Office of the High Commission. 2009. "Information on the mandate" Re independent expert in the field of cultural rights. Available at: https://www.ohchr.org/EN/Issues/CulturalRights/Pages/Mandatelnfo.aspx

United Nations Human Rights. 2013. "The right to artistic freedom.” Geneva: United Nations Human Rights, Office of the High Commissioner. Available at: http://www.ohchr.org/EN/Issues/CulturalRights/Pages/ArtisticFreedom.aspx

Wang, L.-J. 2014. "Cultural rights and citizenship in cultural policy: Taiwan and China." International Journal of Cultural Policy 20 (1): 21-39.

Williams, R. 1981. Culture. Glasgow: Fontana Press.

Woolf, V. 1929. A Room of One's Own. London: Hogarth Press. 